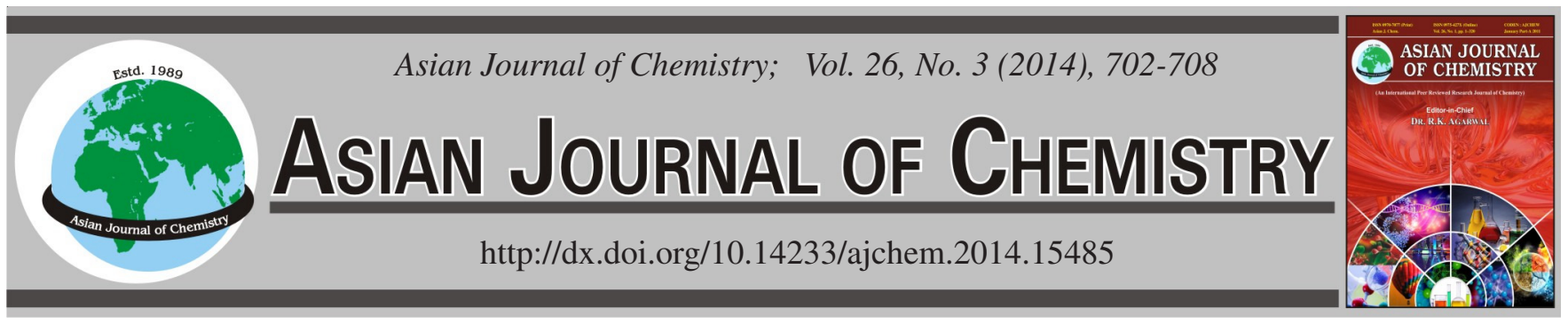

\title{
Physiological Activity of Chinese Lichen (Gyrophora esculenta) Component, Methyl 2,4-Dihydroxy-6-methylbenzoate and the Related Compounds
}

\author{
Shuhsien Wu ${ }^{1}$, Zhendong Zhao ${ }^{2, *}$, Yoshiharu OKada ${ }^{3}$, Yoshiyuki Watanabe ${ }^{3}$, Toshiyuki Takahata ${ }^{1}$, \\ Toshio Inoue ${ }^{4}$, Eiji Otsubo ${ }^{5}$, Jing Wang ${ }^{2}$, Yanju Lu ${ }^{2}$ and Masato Nomura, ${ }^{3, *}$
}

${ }^{1}$ Graduate School of Systems Engineering, Major of Systems Engineering, Kinki University, Takayaumenobe 1, Higashihiroshima, Hiroshima 739-2116, Japan

${ }^{2}$ Institute of Chemical Industry of Forest Products, CAF; National Engineering Lab. for Biomass Chemical Utilization; Key and Open Lab. on Forest Chemical Engineering, SFA; Key Lab. of Biomass Energy and Material, Jiangsu Province, Nanjing 210042, China. No. 16, Suojin Wucun, Nanjing 210042, P.R. China

${ }^{3}$ Department of Biotechnology and Chemistry, Faculty of Engineering, Kinki University, Takayaumenobe 1, Higashihiroshima, Hiroshima, 739-2116, Japan

${ }^{4}$ Department of Pharmaceutical Health Care and Life Sciences, Nihon Pharmaceutical University; Ina-machi 10281, Kida-Adachi, Saitama, 362-0806, Japan

${ }^{5}$ Research Scientist, Research Scientist, Mitsubishi Tanabe Parma Inc, Kisarazu, Chiba, Japan

*Corresponding authors: E-mail: zdzhao@189.cn; nomura@hiro.kindai.ac.jp

Received: 14 March 2013;

Accepted: 13 June 2013;

Published online: 30 January 2014;

AJC-14618

\begin{abstract}
It was confirmed that there was a higher expression of antioxidant potential in methyl 2,4-dihydroxy-6-methylbenzoate (orsellinic acid methyl ester) (2), which was isolated from methanol extract oil of Chinese lichen Gyrophora esculenta rather than from commercialized ascorbic acid. Taking this into account, 4 types of compounds-(4-7) which are known to be related to compound (2)-have been synthesized by using 2,4-dihydroxy benzoic acid (3) as starting material. After that, some physiological activity tests on these compounds have been conducted in the following aspects: antioxidant potential, cytotoxicity, cytokine suppressant effect and histamine liberation inhibition and the effects have been evaluated, respectively. The result shows that (2) and methyl 2,4-dihydroxybenzoate (4) showed high radical expression in both antioxidant potential and histamine liberation inhibition. It was also found that none of these compounds expresses cytotoxicity.
\end{abstract}

Keywords: Chinese lichen, Gyrophora esculenta, Methyl 2,4-dihydroxy-6-methylbenzoate, Cytokine, Histamine, Antioxidant.

\section{INTRODUCTION}

In modern society, it is reported that overstress has been one of obstacles to human body's mental and physical health ${ }^{1}$. For instance, so-called lifestyle-related diseases (cancer, hardening of the arteries, hypertension, diabetes, etc.) are mainly caused by active oxygen and free radical ${ }^{2,3}$ formed excessively in body, which induce various diseases that are caused by cell damages because of protein denaturation, lipoperoxidation, nucleolytic degradation and enzyme inactivation ${ }^{4,5}$. Recently, health-consciousness has been promoted and it is highly accepted that it would be beneficial to take traditional food in which there are active compositions for prevention of disease or for antiaging $^{6}$. Lichen has been utilized for food since the ancient time and is considered to contain its special compositions because of its growth as homobium of fungi and algae $e^{7,8}$. It is also reported that lichen is effective to inhibit lifestyle-related diseases such as hypertension and hypercholesteremia ${ }^{9}$.
Gyrophora esculenta (Miyoshi), also known as Umbilicaria esculenta (Miyoshi) Minks, grows on the surface of the rock, or the outer covering of tree trunk; and distributes widely, from extratropical belt eastern Asia such as China, Japan and Korea, to rigid areas such as Himalayan. Umbilicariaceae looks like approximately rounded thin leaf-like flake, with grey surface and black back side along with spiny thick fines. It grows slowly for $1 \mathrm{~cm}$ every two or three years ${ }^{7,8,10}$. Hashimoto et al. ${ }^{11,12}$ reported that lichens iwatake would play roles in physiological activity to anticancer, anti-inflammatory and glycuresis prophylactic. Therefore, in this paper, authors investigated and identified an anti-oxidative compound that is contained in the oily extract from the Chinese lichens Gyrophora esculenta (Miyoshi), as well as several analogous compounds related to this active compound. It is discovered that the physiological activities of the compounds are relatively different corresponding to their different substituents. The 
physiological activities have been investigated on antioxidation, cytotoxicity, cytokine production suppression and histamine release inhibition and reported hereafter.

\section{EXPERIMENTAL}

Material and extraction: Chinese lichens $283 \mathrm{~g}$, which was collected in May 2008 at Zhangjiajie, Hunan Province, China, was dried, porphyrized and then extracted with methanol (3 L) at room temperature $(20 \pm 2){ }^{\circ} \mathrm{C}$ for 1 month. A methanol leach $(400 \mathrm{~mL})$ was taken after solid residue had been filtrated. A brown oily extract $3 \mathrm{~g}$ was obtained from the methanol leach when methanol was evaporated out under vacuum.

Melting point was determined with melting point measuring instrument (MODEL MP-21Yamato Scientific Co., Ltd.). For structural identification, IR spectrum by KBr plate (FTIR8100A, Shimadzu Co.), ${ }^{1} \mathrm{H}$ and ${ }^{13} \mathrm{C}$ NMR in $\mathrm{CDCl}_{3}$ solvent (JNM-EX 400WB Type FT, Japan Electronic Co., Ltd.) were determined and analyzed. GC-MS (Hewlett Packerd HP 6890 GC, Hewlett Packerd HP 5972 MSD, Shimadzu Co.) was underwent with TC-1 Column $(\varphi 0.25 \mathrm{~mm} \times 30 \mathrm{~m}$, I.D. 1.0 $\mu \mathrm{m})$, under conditions of column temp $50^{\circ} \mathrm{C}$ [ 5 min holding] $270{ }^{\circ} \mathrm{C}\left[3^{\circ} \mathrm{C} / \mathrm{min}\right]$, injection temp $240^{\circ} \mathrm{C}$, interface temp $230^{\circ} \mathrm{C}$, ionization voltage $1.3 \mathrm{kV}$, carrier gas $\mathrm{He}$, flow rate $2 \mathrm{~mL} / \mathrm{min}$. And the structures were estimated through Library NIST (National Institute of Standards and Technology) WebBook.

Solvent fractionations and activity tests: Solvent fractionations of oily extract $3 \mathrm{~g}$ were carried out with hexane, diethyl ether and ethyl acetate in sequence and $0.681,0.788$ and $0.037 \mathrm{~g}$ of oily extracts were obtained, respectively after evaporating solvents. Thereafter, DPPH (1,1-diphenyl-2picrylhydrazyl) radical scavenging effect test and superoxide dismutase (SOD) inhibition test of the fractionations have been done. The results (Table-1) showed that diethyl ether fractionation had DPPH radical scavenging effect. Therefore, $0.770 \mathrm{~g}$ of the oily diethyl ether fractionation was separated through column chromatography (Silica gel 60, eluting solvent:hexane and ethyl acetate in volume ratio of 1:9) into 4 fractionations (A-1)-(A-4) ((A-1): $0.237 \mathrm{~g},(\mathrm{~A}-2): 0.041 \mathrm{~g},(\mathrm{~A}-3): 0.021 \mathrm{~g}$, (A-4): $0.146 \mathrm{~g})$. Further active oxygen inhibition test indicated that fractionation (A-4) was active (Table-2), so the oily fractionation (A-4) (0.1 g) was separated with thin layer chromatography (Silica gel 60, developing solvent is hexane and ethyl acetate in volume ratio of 3:2) into five fractions with $R_{\mathrm{f}}$ values of 0.76((A4-1), 0.014 g), 0.55((A4-2), $0.052 \mathrm{~g}), 0.45((\mathrm{~A} 4-3)$, $0.020 \mathrm{~g}), 0.39((\mathrm{~A} 4-4), 0.010 \mathrm{~g})$ and $0.27((\mathrm{~A} 4-5), 0.028 \mathrm{~g})$, respectively, which were recovered with acetone extraction.

\begin{tabular}{|c|c|c|}
\hline \multicolumn{3}{|c|}{$\begin{array}{c}\text { TABLE-2 } \\
\text { INHIBITION OF SOD-LIKE ACTIVITY } \\
\text { FOR FRACTIONS (A-1)-(A4-5) }\end{array}$} \\
\hline \multirow{2}{*}{ Fraction } & \multicolumn{2}{|c|}{ Inhibition rate $(\%)$} \\
\hline & $0.1^{\mathrm{a}}$ & 1.0 \\
\hline (A-1) & 17.7 & 24.7 \\
\hline$(\mathrm{A}-2)$ & 18.1 & 24.5 \\
\hline (A-3) & 16.0 & 36.0 \\
\hline$(\mathrm{A}-4)$ & 23.3 & 56.0 \\
\hline (A4-1) & 2.4 & 2.4 \\
\hline$(\mathrm{A} 4-2)$ & 20.6 & 72.8 \\
\hline (A4-3) & 11.6 & 32.5 \\
\hline (A4-4) & 6.5 & 16.1 \\
\hline$(\mathrm{A} 4-5)$ & 9.9 & 15.8 \\
\hline Ascorbic acid & 12.6 & 98.7 \\
\hline
\end{tabular}

3,5-Dihydroxytoluene (orsellinol) (1): The oily fraction (A4-1) was purified with TLC (Silica gel 60, developing solvent:hexane and ethyl acetate in volume ratio of $2: 3$ ), then recovered by acetone with $\mathrm{R}_{\mathrm{f}}$ value of 0.36 spot to obtain white crystalline $0.006 \mathrm{~g}$ (m.p. $\left.56-59^{\circ} \mathrm{C}\right)^{13,14}$. The structure of this compound was estimated as 3,5-dihydroxytoluene with GCMS m/z (\%): 124[M] $]^{+}(100 \%), 123(48), 95(11), 78(5), 67(6)$, 55(12), 51(14), 41(14), 39(24), 18(6).

Methyl 2,4-dihydroxy-6-methylbenzoate (orsellinic acid methyl ester) (2): The spot at TLC $\mathrm{R}_{\mathrm{f}}$ value 0.55 (A4-2) collected above was extracted with acetone after drying and then was separated with TLC (silica gel 60, developing solvent is hexane and ethyl acetate in volume ratio of $1: 1$ ) followed by acetone extraction to obtain a white crystalline compound $\left(0.040 \text { g, m.p. } 139-143{ }^{\circ} \mathrm{C}\right)^{14}$. The structure of the compound was identified as methyl 2,4-dihydroxy-6-methylbenzoate ${ }^{15}$ with IR (KBr, $\left.v_{\max }, \mathrm{cm}^{-1}\right)$ : 3370(-OH), 3316(-OH), 1651(C=O), $1616(\mathrm{C}=\mathrm{C})$ ); ${ }^{1} \mathrm{H}$ NMR $\delta$ (in $\left.\mathrm{CDCl}_{3}\right): 2.49\left(3 \mathrm{H}, \mathrm{s},-\mathrm{CH}_{3}\right), 3.93$ $\left(3 \mathrm{H}, \mathrm{s},-\mathrm{OCH}_{3}\right), 5.37(1 \mathrm{H}, \mathrm{s},-\mathrm{OH}), 6.24(1 \mathrm{H}, \mathrm{s}, \mathrm{ph}-\mathrm{H}), 6.29$ $(1 \mathrm{H}, \mathrm{s}, \mathrm{ph}-\mathrm{H}), 11.79(1 \mathrm{H}, \mathrm{s},-\mathrm{OH}) ;{ }^{13} \mathrm{C} \mathrm{NMR} \delta$ (in $\left.\mathrm{CDCl}_{3}\right)$ : 24.25, 51.78, 100.97, 105.36, 110.99, 143.62, 159.76, 164.86, 171.66); MS m/z (\%): 182[M] $]^{+}, 150(100), 122(63), 94(20)$, 69(30), 66(27), 53(25).

\section{Syntheses}

Synthesis of methyl 2,4-dihydroxybenzoate (4) $)^{16,17}$ : 2,4Dihydroxybenzoate $(3) 1.54 \mathrm{~g}\left(10 \times 10^{-3} \mathrm{~mol}\right)$ resolved in $50 \mathrm{~mL}$ of methanol was put into $300 \mathrm{~mL}$ flask connected with a refluxing condenser. $10 \mathrm{~mL}$ of concentrated sulfuric acid was added as a catalyst. Then, the mixture was refluxed for $24 \mathrm{~h}$ at $70^{\circ} \mathrm{C}$. Thereafter, reactant was transferred into icy water

\begin{tabular}{|c|c|c|c|c|}
\hline \multicolumn{5}{|c|}{$\begin{array}{l}\text { TABLE-1 } \\
\text { DPPH RADICAL SCAVENGING EFFECT ASSAY AND SOD ASSAY OF Gyrophora esculenta (CHINA) }\end{array}$} \\
\hline \multirow{3}{*}{ Extract $^{\mathrm{a}}$} & \multicolumn{2}{|c|}{ DPPH radical scavenging assay } & \multirow{2}{*}{\multicolumn{2}{|c|}{$\begin{array}{c}\text { SOD-like assay } \\
\text { Inhibition rate }(\%)\end{array}$}} \\
\hline & \multirow{2}{*}{ Scavenging rate $(\%)^{\mathrm{b}}$} & \multirow{2}{*}{$\mathrm{SC}_{50}{ }^{\mathrm{c}}$} & & \\
\hline & & & $0.1 \mathrm{~g} / \mathrm{L}$ & $1 \mathrm{~g} / \mathrm{L}$ \\
\hline Methanol & 35.9 & 370.9 & 22.2 & 23.5 \\
\hline Hexane & 25.4 & $>400$ & 9.7 & 10.7 \\
\hline Diethyl ether & 63.3 & 113.7 & 22.7 & 33.9 \\
\hline Ethyl acetate & 84.5 & 43.9 & 28.8 & 49.5 \\
\hline Residue & 23.0 & $>400$ & 8.7 & 9.3 \\
\hline$\alpha$-Tocopherol $(\mathrm{Ve})^{\mathrm{d}}$ & 100.0 & 6.0 & - & - \\
\hline Ascorbic acid & - & - & 12.6 & 88.9 \\
\hline
\end{tabular}

${ }^{\mathrm{a}}$ Concentration $(1 \mathrm{~g} / \mathrm{L}) .{ }^{\mathrm{b}}$ Corrected concentration $(0.2 \mathrm{~g} / \mathrm{L}) .{ }^{\mathrm{c}} 50 \%$ scavenging concentration $(\mathrm{mg} / \mathrm{L}) .{ }^{\mathrm{d}}$ Concentration $(1 \mathrm{mM})$. 
$(100 \mathrm{~mL})$ to stop the reaction. The oil matter was extracted with diethyl ether and then treated with saturated aqueous solution of $\mathrm{NaHCO}_{3}$, dried with anhydrous magnesium sulfate; at last the solvent was distillated. The obtained yellowish oil was separated and purified with TLC (developing solvent is diethyl ether and chloroform in volume ration of 1:1) to give $1.52 \mathrm{~g}$ of compound (4) (yield $90.5 \%$ ). The structure was identified with ${ }^{1} \mathrm{H} \mathrm{NMR} \delta$ (in $\left.\mathrm{CDCl}_{3}\right): 3.92\left(3 \mathrm{H}, \mathrm{s},-\mathrm{COOCH}_{3}\right)$, 5.23(1H, s, $-\mathrm{OH}), 6.37(2 \mathrm{H}, \mathrm{d}, J=8.61 \mathrm{~Hz}, \mathrm{ph}-\mathrm{H}), 7.74(1 \mathrm{H}, \mathrm{d}$, $J=8.61 \mathrm{~Hz}$, ph-H), $10.97(1 \mathrm{H}, \mathrm{s},-\mathrm{OH}) ;{ }^{13} \mathrm{C} \mathrm{NMR} \delta$ (in $\left.\mathrm{CDCl}_{3}\right)$ : 51.98, 103.01, 105.85, 107.59, 131.74, 161.53, 163.46, 170.08; MS m/z (\%): $168[\mathrm{M}]^{+}, 137(35), 136(100), 108(44)$, 95(6), 81(12), 80(14), 69(15), 53(22).

Synthesis of methyl 2-hydroxy-4-methoxybenzoate $(5)^{18}$ and methyl 2,4-dimethoxybenzoate (6): The obtained compound (4) $0.17 \mathrm{~g}\left(1.0 \times 10^{-3} \mathrm{~mol}\right)$ was resolved into $10 \mathrm{~mL}$ of distillated THF under an argon atmosphere and $0.05 \mathrm{~g}$ of sodium hydride was added, stirred for $24 \mathrm{~h}$ at room temperature $(20 \pm 2)^{\circ} \mathrm{C}$. Iodomethane $0.1 \mathrm{~g}$ was added into reactant and then continuously stirred for more than $24 \mathrm{~h}$ at room temperature. After that, $5 \mathrm{~mL}$ of $2 \mathrm{~mol} / \mathrm{L} \mathrm{HCl}$ solution was added to stop the reaction. The oily matter was extracted with diethyl ether, washed with saturated aqueous solution of $\mathrm{NaCl}$, dried with anhydrous magnesium sulfate. After removing the solvent by distillation, the obtained oil was separated with TLC (developing solvent is chloroform and methanol in volume ratio of 9:1) into 2 spots that were collected and recovered with acetone, respectively.

The oil with TLC $R_{f}$ value 0.78 was purified with further TLC (developing solvent is hexane and ethyl acetate in volume ratio of 8:2) and compound (5) (0.018 g, yield 9.8\%) was obtained. The structure was identified clearly as methyl 2hydroxy-4-methoxybezoate with ${ }^{1} \mathrm{H}$ NMR $\delta$ (in $\mathrm{CDCl}_{3}$ ): 3.85 $\left(3 \mathrm{H}, \mathrm{s},-\mathrm{OCH}_{3}\right), 3.92\left(3 \mathrm{H}, \mathrm{s},-\mathrm{COOCH}_{3}\right), 6.44(2 \mathrm{H}, \mathrm{d}, \mathrm{J}=8.18 \mathrm{~Hz}$, ph-H), 7.74(1H, d, $J=9.16 \mathrm{~Hz}, \mathrm{ph}-\mathrm{H}), 10.99(1 \mathrm{H}, \mathrm{s},-\mathrm{OH})$; ${ }^{13} \mathrm{C} \mathrm{NMR} \delta$ (in $\mathrm{CDCl}_{3}$ ) : 51.92, 55.41, 100.50, 105.28, 107.43, 131.04, 163.55, 165.37, 170.20; MS m/z (\%): 182[M] $]^{+}$, 151(28), 150(100), 122(39), 107(25), 95(7), 79(16), 63(11), 51(20).

Another oil matter at spot with TLC $\mathrm{R}_{\mathrm{f}}$ value of 0.50 was also separated by TLC (developing solvent was diethyl ether and chloroform in volume ratio of 1:9) to give compound (6) $(0.025 \mathrm{~g}$, yield $12.5 \%)$. Its structure was identified clearly as methyl 2,4-dimethoxybenzoate through ${ }^{1} \mathrm{H} \mathrm{NMR} \delta$ (in $\mathrm{CDCl}_{3}$ ): $3.85\left(3 \mathrm{H}, \mathrm{s},-\mathrm{OCH}_{3}\right), 3.86\left(3 \mathrm{H}, \mathrm{s},-\mathrm{OCH}_{3}\right), 3.90\left(3 \mathrm{H}, \mathrm{s}, \mathrm{COOCH}_{3}\right)$, $6.50(2 \mathrm{H}, \mathrm{d}, J=7.81 \mathrm{~Hz}, \mathrm{ph}-\mathrm{H}), 7.86(1 \mathrm{H}, \mathrm{d}, J=8.91 \mathrm{~Hz}, \mathrm{ph}-\mathrm{H})$; ${ }^{13} \mathrm{C}$ NMR $\delta$ (in $\mathrm{CDCl}_{3}$ ) : 51.66, 55.41, 55.90, 98.79, 104.35, 112.05, 133.70, 161.10, 164.03, 165.91; MS m/z (\%): $196[\mathrm{M}]^{+}$, 166(10), 165(100),163(18),150(6), 135(12), 122(13), 107(14), 92(6), 77(12), 63(13), 51(16), 44(17).

Synthesis of methyl 4-hydroxy-2-methoxybenzoate (7) ${ }^{19}$ : The synthesized compound (4) $0.84 \mathrm{~g}\left(5.0 \times 10^{-3} \mathrm{~mol}\right)$ was resolved into $15 \mathrm{~mL}$ of dichloromethane under ice-bath (below $0{ }^{\circ} \mathrm{C}$ ). $0.84 \mathrm{~g}$ of triethylamine was added and stirred. Then, benzoyl chloride $0.77 \mathrm{~g}$ solved in chloromethane $(2 \mathrm{~mL})$ and stirred for $24 \mathrm{~h}$ at room temperature. Thereafter, $5 \mathrm{~mL}$ of $2 \mathrm{~mol} / \mathrm{L} \mathrm{HCl}$ solution was put in and stopped the reaction. The reacted oil was washed with saturated solution of sodium chloride, dried with anhydrous magnesium sulfate. The oil matter obtained after distillation of solvent was separated and purified with TLC (developing solvent is chloroform) to give methyl 4-benzoyloxy-2-hydroxybenzoate (4a) (1.13 g, yield $83.1 \%)$. The structure was identified clearly with ${ }^{1} \mathrm{H}$ NMR $\delta$ (in $\left.\mathrm{CDCl}_{3}\right): 3.97\left(3 \mathrm{H}, \mathrm{s},-\mathrm{COOCH}_{3}\right), 6.80(1 \mathrm{H}, \mathrm{dd}, J=2.26$, $8.73 \mathrm{~Hz}, \mathrm{ph}-\mathrm{H}), 6.89(1 \mathrm{H}, \mathrm{d}, J=2.20 \mathrm{~Hz}, \mathrm{ph}-\mathrm{H}), 7.53(2 \mathrm{H}, \mathrm{t}$, $J=7.72 \mathrm{~Hz}, \mathrm{ph}-\mathrm{H}), 7.66(1 \mathrm{H}, \mathrm{t}, J=7.45 \mathrm{~Hz}, \mathrm{ph}-\mathrm{H}), 7.91(1 \mathrm{H}, \mathrm{d}$, $J=8.73 \mathrm{~Hz}$, ph-H), 8.19(2H, d, $J=7.14 \mathrm{~Hz}, \mathrm{ph}-\mathrm{H}), 10.94(1 \mathrm{H}$, s, -OH); MS m/z (\%): $272[\mathrm{M}]^{+}, 105$ (100), 77(35), 51(18).

Afterwards, compound (4a) $0.66 \mathrm{~g}\left(2.4 \times 10^{-3} 0.44 \mathrm{~g}\right.$ of mol) was solved in $30 \mathrm{~mL}$ THF under an argon atmosphere, $0.44 \mathrm{~g}$ of $\mathrm{KOH}$ was added in and stirred for $0.5 \mathrm{~h}$ at room temperature $(20 \pm 2){ }^{\circ} \mathrm{C}$. Thereafter, $0.7 \mathrm{~mL}$ methyl sulfate was added at the same temperature and stirred for $12 \mathrm{~h}$. After the reaction was stopped by adding water, oil product was isolated with adding $20 \mathrm{~mL}$ of $2 \mathrm{~mol} / \mathrm{L} \mathrm{HCl}$ solution and then was extracted with ethyl acetate followed by washing with saturated $\mathrm{NaCl}$ solution, drying with magnesium sulfate. The obtained oil was separated and purified by TLC (developing solvent is diethyl ether and chloroform in volume ratio of 5:95) to give methyl 4-benzoyloxy-2-methoxybenzoate (4b) $0.61 \mathrm{~g}$ (yield $88.6 \%$ ). Its structure was identified clearly with ${ }^{1} \mathrm{H}$ NMR (in $\mathrm{CDCl}_{3}$ ): $3.87\left(3 \mathrm{H}, \mathrm{s},-\mathrm{OCH}_{3}\right), 3.88\left(3 \mathrm{H}, \mathrm{s},-\mathrm{COOCH}_{3}\right), 6.86$ $(1 \mathrm{H}, \mathrm{dd}, J=2.20,8.42 \mathrm{~Hz}$, ph-H), $6.89(1 \mathrm{H}, \mathrm{d}, J=6.23 \mathrm{~Hz}$, ph-H), 7.49 (2H, t, $J=7.69 \mathrm{~Hz}$, ph-H), $7.63(1 \mathrm{H}, \mathrm{t}, J=7.45$ $\mathrm{Hz}$, ph-H), 7.90 (1H, d, $J=8.42 \mathrm{~Hz}$, ph-H), 8.18 (2H, dd, $J=$ 1.34, $8.42 \mathrm{~Hz}, \mathrm{ph}-\mathrm{H})$; MS m/z(\%): $286[\mathrm{M}]^{+}, 255(2), 107(2)$, 106(10), 105(100), 77(41), 63(3), 51(19).

Furthermore, the mixture of $(\mathbf{4 b}) 0.088 \mathrm{~g}\left(0.31 \times 10^{-3} \mathrm{~mol}\right)$ solved in $6 \mathrm{~mL}$ of methanol with $0.026 \mathrm{~g}$ sodium methoxide was stirred for $12 \mathrm{~h}$ at room temperature. Then, $5 \mathrm{~mL}$ of $2 \mathrm{~mol} / \mathrm{L}$ $\mathrm{HCl}$ solution was added to stop the reaction. The reacted oil was extracted with ethyl acetate, washed with saturated salt solution and dried by anhydrous magnesium sulfate. The oil product obtained from the solvent evaporation was separated by TLC (developing solvent is hexane and ethyl acetate in volume ratio of 2:3) to give out compound (7) $(0.041 \mathrm{~g}$, yield $73.0 \%)$. The structure of compound (7) was confirmed by ${ }^{1} \mathrm{H}$ $\mathrm{NMR}$ (in $\mathrm{CDCl}_{3}$ ): 3.74(3H, s, $\left.-\mathrm{OCH}_{3}\right), 3.86\left(3 \mathrm{H}, \mathrm{s},-\mathrm{COOCH}_{3}\right)$, 6.47(1H, s, ph-H), 6.49 (1H, d, $J=2.32 \mathrm{~Hz}, \mathrm{ph}-\mathrm{H}), 7.61(1 \mathrm{H}, \mathrm{s}$, - $\mathrm{OH}$ ), $7.79(1 \mathrm{H}, \mathrm{d}, J=8.91 \mathrm{~Hz}, \mathrm{ph}-\mathrm{H}) ;{ }^{13} \mathrm{C} \mathrm{NMR}$ (in $\mathrm{CDCl}_{3}$ ): 51.80, 55.71, 99.38, 107.16, 111.21, 133.86, 161.14, 161.53, 166.32; MS m/z (\%): $182\left[\mathrm{M}^{+}, 152(8), 151\right.$ (100), 149(19), 136(6), 121(13), 108(17), 93(10), 80(7), 65(16), 52(15), 51(15).

\section{Physiological activity tests}

DPPH radical scavenging test: The above obtained compounds were solved, respectively with ethanol to prepare a testing solution in $1 \mathrm{~g} / \mathrm{L}$ concentration and then determined at $517 \mathrm{~nm}$ by spectrophotometer according to the literature ${ }^{20}$.

Active oxygen inhibition (SOD) test: The above obtained compounds were solved, respectively in DMSO to prepare a testing solution in $3 \mathrm{mM}$ concentration. Then the testing solutions were determined with SOD activity detection kit (manufactured by Wako Pure Chemical Industries, Ltd.) by a microplate reader (MTP-300, Corona Electric Co., Ltd.) at $560 \mathrm{~nm}$ according to the literature ${ }^{20}$. 
BAP test: The antioxidative potency of above testing materials were determined with BAP test kit (made by Uisuma) at $37^{\circ} \mathrm{C}$ by spectrophotometer (FRAS 4 , made by Uisuma) through $\mathrm{Fe}^{3+}$ concentration determination according to the literature ${ }^{21}$.

Cytotoxicity test: The alveolar epithelial a II-type cells A549 derived from human (ATCC: American type cell culture) were used for the cytotoxicity test. Fetal bovine serum (FBS), which was inactivated, for cell culture, Dulbeccos Modified Eagle Medium (DMEM), phosphate buffer saline (PBS), $0.05 \%$ trypsin-EDTA solution, DMSO for resolving antibiotic and compounds are all the commodities made by GIBCO. The subculture of A549 cells was undergone for $24 \mathrm{~h}$ according to the literature ${ }^{22}$. After standing for $0.5 \mathrm{~h}$ at room temperature, the Cell Titer-Glo Luminescence reagent (Promega Corporation) $100 \mu \mathrm{L}$ were added for the measurement of living cells. Vibrate for 2 min to react with ATP in cells and then the number of viable cells was calculated through measure the colour in a luminometer.

Cytokin production suppression test: The cells A549 subcultured, which were at subconfluent state after subculture, were put into 96 well plates for cell culture and crowded in sown concentration of 2000 per well $(2000 / 100 \mu \mathrm{L})$ to be attached to the wells by incubation for one night. After the stiction of cells were confirmed, the medium was removed, rhIL-1beta (Manufactured by R \& D System Co.), which was adjusted to concentration of $200 \mu \mathrm{M}$, DMEM Medium solution $100 \mu \mathrm{L}$ contained $10 \%$ FBS and the predetermined concentration of test substance $(1-100 \mu \mathrm{M}) 100 \mu \mathrm{L}$ were added, respectively and then were further cultivated for $24 \mathrm{~h}$. Lastly, IL-8 in the culture medium were determined with ELISA (enzyme-linked immunosorbent assay) kit according to literature $^{23}$.

Histamine release inhibition test: Male Wistar rats (7 week age, weight 190-220 g, Saitama Experimental Animal Supply Co.) were fed in a room with air-conditioning equipment at room temperature $(24 \pm 2)^{\circ} \mathrm{C}$ and humidity $(45 \pm 15) \%$, then treated according to literatures ${ }^{24,25}$, histamine content in the supernatant was determined by Autoanalyzer II (Blanc LOUBET Co., Ltd.).

\section{RESULTS AND DISCUSSION}

Active compounds and their activities: The crude oil obtained from methanol extraction of the Chinese lichens was analyzed by GC-MS (TC-1 column). As shown in Fig. 1, 3,5dihydroxytoluene (orsellinol) (1) and methyl 2,4-dihydroxy6-methylbenzoate (orsellinic acid methyl ester) (2) were identified as dominate components (GLC \%, 44:56). The oil product was extracted by hexane, diethyl ether and ethyl acetate, in sequence, from the crude oil. The antioxidative potentials of these fractions were investigated according to DPPH radical scavenging test and active oxygen inhibition (SOD) test. The results showed that the fraction extracted by ethyl acetate gave the highest DPPH radical scavenging effect (Table-1). Due to the result that the oily extractions using diethyl ether and ethyl acetate as solvents presented high activity in the active oxygen inhibition (SOD) test, the relationship between the active oxygen inhibitions (SOD) and concentrations was investigated. Under<smiles>Cc1cc(O)cc(O)c1</smiles><smiles>CC(=O)c1c(C)cc(O)cc1O</smiles>

Fig. 1. Structure of compounds (1) and (2)

the concentrations of $0.1 \mathrm{~g} / \mathrm{L}$, the oil fractionation $(22.7 \%)$ extracted by diethyl ether and the oil fractionation $(18.8 \%)$ extracted by ethyl acetate $(18.8 \%)$ showed higher SOD-like activities than the commercially available ascorbic acid (12.6\%). Therefore, the column chromatography (Silica gel 60 , eluting solvent: hexane and ethyl acetate in volume ration of 1:9) is used to separate the effective compounds from the fraction extracted by diethyl ether. Then, as shown in Table-2, fractionations (A-1)-(A-4) were collected and (A-4) showed high inhibition effects, while the active oxygen inhibitions (SOD) test was pursued in comparison with the commercial ascorbic acid (0.1 g/L, 12.6\%). In addition, (A4-2) was further isolated from (A-4) fraction as white crystalline (2) by using column chromatography (Silica gel 60, eluting solvent:hexane and ethyl acetate in volume ration of 1:1). The active oxygen inhibition values were determined below the concentration of $0.1 \mathrm{~g} / \mathrm{L}$. It showed that with the increasing concentration from 0.1-1.0 g/L, the active oxygen inhibition values were also increased from $20.6 \%$ to $72.8 \%$, which were higher than that of ascorbic acid, respectively. Therefore, we believe that compound (2), an important component identified in the methanol extract oil from Chinese lichens, has great potential to be used as antioxidative prospect.

Synthesis of the related compounds and their activities: Based on the physiological activities discovered from the compound (2) which was isolated from methanol extract of the Chinese lichens, the related compounds were synthesized as shown in Fig. 2 as reaction pathway focused on the functional group. In other words, four compounds, including methyl 2,4dihydroxybenzoate (4), methyl 2-hydroxy-4-methoxybenzoate (5), methyl 2,4-dimethoxybenzoate (6) and methyl 4-hydroxy2-methoxybenzoate (7), were synthesized using 2,4-dihydroxybenzoic acid (3) as the staring material. As discussed previously, physiological activities of the compound (2) and its derivatives such as DPPH radical scavenging effects, antitumor activity and antibacterial activity, etc. have been reported ${ }^{26-28}$. Therefore, in this paper, active oxygen inhibiting effects at different concentrations have been studied to evaluate a new physiological activity. As a conclusion, it has been confirmed that expression of the effect for compounds (4) and (7) under the concentration of $1 \mathrm{~g} / \mathrm{L}$ was observed. On the other hand, under the concentration of $0.1 \mathrm{~g} / \mathrm{L}$, compound (7) indicated the inhibition rate at a value of $9.5 \%$, which is close to the value $(12.6 \%)$ of ascorbic acid as a reference material (Table-3).

The above results show that $\mathrm{OH}$ group at $\mathrm{C}_{4}$ position has a significant relationship with the expression of antioxidant capacity, even though there are both hydroxyl groups at $\mathrm{C}_{2}$ and $\mathrm{C}_{4}$ positions of aromatic ring. And the mechanism (Fig. 3) is considered that $\mathrm{C}_{4}-\mathrm{OH}$ group of compound (2) reacts with the active oxygen and forms quinone structure and then $\mathrm{C}_{2}-\mathrm{OH}$ group forms an intramolecular hydrogen bond with $\mathrm{C}_{1}-\mathrm{COOCH}_{3}$, 


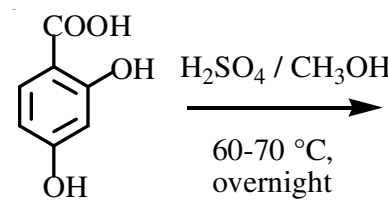

(3)<smiles>COC(=O)c1ccc(O)cc1O</smiles>

(4)

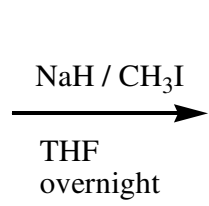

overnight<smiles>COC(=O)c1ccc(OC)cc1OC</smiles>

(6)

$\mathrm{C}_{6} \mathrm{H}_{5} \mathrm{COCl} /\left(\mathrm{C}_{2} \mathrm{H}_{5}\right)_{3} \mathrm{~N} / \mathrm{CH}_{2} \mathrm{Cl}_{2}$, overnight<smiles>CC(=O)c1ccc(OC(=O)c2ccccc2)cc1O</smiles>

(4a)

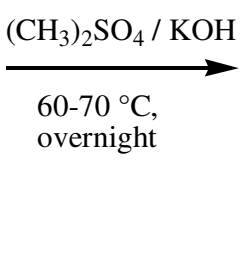

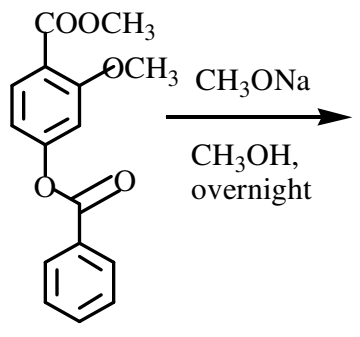

(4b)

Fig. 2. Synthesis of compounds (4-7) from compound (3)

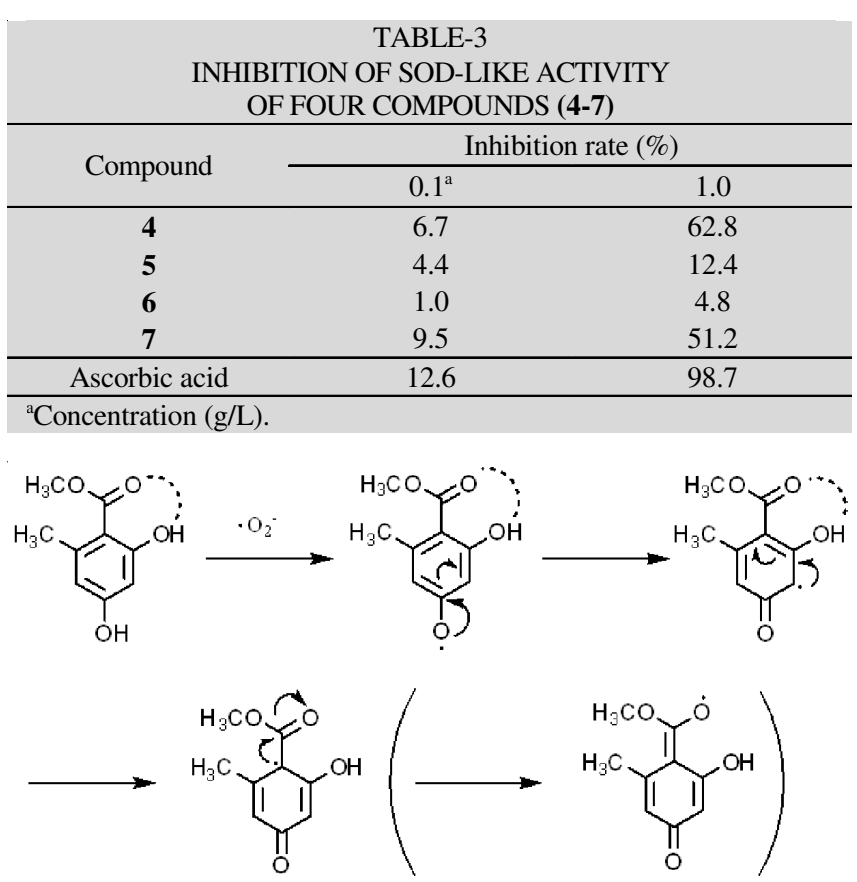

Fig. 3. Plausible structure of methyl 2,4-dihydroxy-6-methylbenzoate radical generated by active oxygen

after that the radical transfers to $\mathrm{C}_{1}-\mathrm{COOCH}_{3}$ and takes place in expression of the activity. According to the report ${ }^{29}$ concerning ethyl 3,4-dihydroxybenzoate as a reactant, the reaction occurred with DPPH radical through electron transferring to the ester carbonyl group without going through quinone structure. Therefore, it was considered that a hydrogen bond forms with $\mathrm{C}_{2}-\mathrm{OH}$ group, while radical transferring occurs between $\mathrm{C}_{1^{-}}$ carbon and $-\mathrm{COOCH}_{3}$ group to approach an equilibrium state and then plays a role in expression of the activity. Similarly, the reason that compound (7) acted as high antioxidant potential is considered that the radical transferred to $-\mathrm{COOCH}_{3}$ group because $\mathrm{C}_{2}-\mathrm{OH}$ group was converted to $-\mathrm{OCH}_{3}$ group leading that the stabilized antioxidant potential was expressed even though there was concentration variation.
Then, the evaluation of antioxidant capacity tests was performed using compounds (2) and (4-7) by BAP test kit. In other words, commercial ascorbic acid and $\alpha$-tocopherol as shown in Table- 4 were tested in different concentrations (0.1$1.0 \mathrm{~g} / \mathrm{L}$ ) to calculate the amounts of ascorbic acid equivalent and $\alpha$-tocopherol equivalent, respectively.

\begin{tabular}{cccccc}
\multicolumn{5}{c}{ TABLE-4 } \\
ANTIOXIDANT POTENTIAL OF \\
ASCORBIC ACID AND $\alpha$-TOCOPHEROL \\
\hline \multirow{2}{*}{ Compound } & $0.01^{\mathrm{a}}$ & 0.1 & 0.3 & 0.6 & 1.0 \\
\hline & 785 & 1335 & 2241 & 4115 & 6412 \\
\hline Ascorbic acid & 780 & 1012 & 1368 & 2237 & 3148 \\
\hline$\alpha$-Tocopherol & & & & &
\end{tabular}

The result showed that compound (7) gave a value of $1119 \mu \mathrm{M}$, which is the same antioxidant capacity with those of either ascorbic acid in concentration of $0.15 \mathrm{~g} / \mathrm{L}$, or $\alpha$-tocopherol in concentration of $0.07 \mathrm{~g} / \mathrm{L}$. The compounds (2), (4), (5) and (6) presented values below $890 \mu \mathrm{M}$, showing high expression of activity in active oxygen inhibition tests. It gave the result that the hydroxyl group located at $\mathrm{C}_{1}$ position of aromatic ring formed intramolecular hydrogen bound with $-\mathrm{COOCH}_{3}$ at $\mathrm{C}_{1}$ position, which resulted a decrease of the expression of the antioxidant capacity. On the other hand, compound (7) did not form any similar intramolecular hydrogen bond, but formed a $p$-coordination from $\mathrm{C}_{4}-\mathrm{OH}$ group against $\mathrm{C}_{1}-\mathrm{COOCH}_{3}$ group.

To investigate the influence of compounds (2), (4-7) on cells, the cytotoxicity test (immunofluorescent method) ${ }^{21}$ ) was performed, with cells A549 as known as alveolar epithelial cell line derived from human. According to the results (Table-5), there was not obviously strong cytotoxicity for any compound since all the cell survival rates were higher than $80 \%$ for these compounds. When the dependence $(100 \mu \mathrm{M})$ concentration was examined against compounds (4) and (7), the cell survival rates are $86.2 \%$ to compound (4) and $88 \%$ to compound (7). 
It was suggested that $\mathrm{OH}$ group at $\mathrm{C}_{4}$ position, which is the functional group to express active oxygen inhibitions effects, not only to be active antioxidant potential, but also affects cells a lot. On contrary, the cell survival rate for compound (2) in concentration of $100 \mu \mathrm{M}$ was $97 \%$, which was higher than the values of compounds (4) and (7). Therefore, the toxicity is considered been alleviated because $\mathrm{C}_{4}-\mathrm{OH}$ group coexisted with $\mathrm{C}_{6}-\mathrm{CH}_{3}$ group.

TABLE-5

A549 CELL TOXICITY FOR COMPOUNDS (2) AND (4-7)

\begin{tabular}{cccccc}
\hline $\begin{array}{c}\text { Concentration } \\
(\mu \mathrm{M})\end{array}$ & $\mathbf{2}$ & $\mathbf{4}$ & $\mathbf{5}$ & $\mathbf{6}$ & $\mathbf{7}$ \\
\cline { 2 - 6 } & 103 & 97 & 110 & 101 & 93 \\
1 & 103 & 90 & 110 & 103 & 91 \\
10 & 97 & 86 & 129 & 104 & 88 \\
100 & & & &
\end{tabular}

It is known that alveolar epithelial cells produce IL-8 which is inflammatory cytokin due to the effects of oxidative stress. Therefore, the anti-inflammation activity tests on the A549 alveolar epithelial cell obtained from human were carried out with ELISA kit for the compounds and the result did not show any cytotoxicity (Table-6). Regardless of the concentration, the compounds (2) and (7) showed some rates of production more than $80 \%$, so it was considered that there is no significant inhibitory effect.

\begin{tabular}{|c|c|c|c|c|c|}
\hline & $\begin{array}{l}\text { ANTII } \\
\text { FOR }\end{array}$ & $\begin{array}{l}\text { TAE } \\
\text { MM } \\
\text { OUUN }\end{array}$ & $\begin{array}{l}\text { N AC } \\
\text { ) AN }\end{array}$ & & \\
\hline & & roduc & he pe & ge of & \\
\hline $\begin{array}{l}\text { Concentration } \\
\text { (uM) }\end{array}$ & & & mpol & & \\
\hline & 2 & 4 & 5 & 6 & 7 \\
\hline 1 & 92 & 107 & 112 & 88 & 104 \\
\hline 10 & 93 & 101 & 104 & 117 & 100 \\
\hline 100 & 91 & 101 & 110 & 94 & 95 \\
\hline
\end{tabular}

However, it was observed that there was a slight inhibitory effect for the subdivided fraction (A-2) and compound (7). From the results, it is considered that the presence of $\mathrm{OH}$ group at $\mathrm{C}_{4}$ position, which is believed to cause an inhibitory effect of active oxygen, also affects the cytokin production inhibitory effect a lot.

The antiallergic reaction of compounds (2-7) was investigated based on the expression of histamine against the allergy suppression involved in the onset of hay fever causing many diseases in recent years. As a comparison substance, a basic polymer compound 48/80 (an itch inducing agent) ${ }^{30}$ causing mast cell degranulation in rat peritoneal was added, then method (histamine release inhibition test) was used to liberate histamine. As a result, it was shown (Table-7) that histamine release inhibitory effects of compound (2) and (4) were with values of $(24.21 \pm 2.08) \%$ and $(21.08 \pm 3.76) \%$, respectively, compared with values of $35.23 \pm 4.53 \%$ of the control group. The $m$-coordination between $\mathrm{C}_{2}-\mathrm{OH}$ and $\mathrm{C}_{4}-\mathrm{OH}$ groups in the structure of compound (4) was considered to be involved in the expression causing histamine release inhibitory effect.

Then, the inhibitory effect was studied according to the $(10,30$ and $100 \mathrm{mg} / \mathrm{L})$ concentration variation for compounds (2) and (4) whose inhibitory effect of histamine was observed.
TABLE-7

ANTIHISTAMINE-RELEASING OF COMPOUNDS (2) AND (4-7)

$\begin{array}{cc}\text { Compound* } & \text { Histamine release }(\%) \\ \text { Control } & 35.23 \pm 4.53 \\ \mathbf{2} & 24.21 \pm 2.08^{* *} \\ \mathbf{4} & 21.08 \pm 3.76^{* *} \\ \mathbf{5} & 34.42 \pm 5.14 \\ \mathbf{6} & 40.01 \pm 3.71 \\ \mathbf{7} & 33.42 \pm 8.27\end{array}$

*Concentration $(\mathrm{mg} / \mathrm{L}) .{ }^{* *} \mathrm{p}<0.05$ compared with the control group (Dunnett's test).

It shows that the compounds have suppressive effects on histamine release by the concentration dependence (Table-8), especially significantly different in $30 \mathrm{mg} / \mathrm{L}$ concentration. Considering that compounds (2) and (4) are similar with the structure of quercetin and resveratrol ${ }^{31,32}$ as known as common antihistamine reagents. The expression mechanism that $\mathrm{OH}$ groups on the aromatic ring convert to the quinone ${ }^{33.34}$ structure and that $-\mathrm{OH}$ groups are in $m$-coordination were considered whether to be involved in the expression of histamine release inhibition.

As a conclusion, it is clear that there is new biological activity found in some specific compounds among lichen compounds and the synthesized relatives and the lichens is expected to be used as a functional food for maintenance and promotion of good health, as well as for prevention of lifestylerelated diseases.

\section{Conclusion}

The substance (2) with antioxidant capacity was isolated from the Chinese lichens Gyrophora esculenta grown in harsh environments and the related compounds (4-7) were synthesized at the same time, to evaluate the physiological activity such as cytotoxicity, cytokin inhibitory effect and inhibitory effect of histamine release for these compounds. The results showed that compound (2) indicated even higher inhibition rate $24.4 \%$ in $0.1 \mathrm{~g} / \mathrm{L}$ concentration than the value $(0.1 \mathrm{~g} / \mathrm{L}$, $12.6 \%$ ) of ascorbic acid as antioxidant capacity. It was confirmed that there is no cell toxicity for compound (2) expressed the inhibitory activity of active oxygen, because of cell survival rate of $80 \%$ or higher while the cytotoxicity was examined with A549 type II alveolar epithelial cells derived from human. At the same time, the inhibitory effect was also examined cytokin production and it was judged that there was not inhibitory effect of IL-8 (i.e. inflammatory cytokin) production, because cytokin production rate was more than $80 \%$. On the other hand, it was confirmed that the inhibitory effect of histamine release is expressed by compounds (2) and (4) due to the inhibitory effect on histamine release with rat peritoneal mast cells. These results showed that compound (2) expressed a favorable physiological activity, which is especially antioxidant activity, as well as cytotoxicity and the inhibitory effect of histamine release.

\section{ACKNOWLEDGEMENTS}

This study was supported by the International $\mathrm{S} \& \mathrm{~T}$ Cooperation Program of China (ISTCP) (Grant No. 2011DFA32440) and the Commonweal Research (Grant No. CAFINT2009C02) that should be grateful. 
TABLE-8

ANTIHISTAMINE-RELEASING OF COMPOUNDS (2) AND (4) IN DEFERENT CONCENTRATIONS

\begin{tabular}{cccc}
\hline \multirow{2}{*}{ Compound* } & \multicolumn{3}{c}{ Histamine release $(\%)$} \\
\cline { 2 - 4 } & Control & 10 & 30 \\
\hline $\mathbf{2}$ & $31.24 \pm 3.11$ & $27.43 \pm 4.96$ & $14.87 \pm 2.97 * *$ \\
$\mathbf{4}$ & $36.64 \pm 2.67$ & $30.23 \pm 4.57$ & $17.42 \pm 7.24 * *$ \\
\hline$*$ Concentration $(\mathrm{mg} / \mathrm{L}) * * * 2<0.05$ compared with the control group (Dunnett's test). & $14.04 \pm 5.14 * *$ & $1.35 * *$ \\
\hline
\end{tabular}

*Concentration (mg/L). ** $p<0.05$ compared with the control group (Dunnett's test).

\section{REFERENCES}

1. T. Tsuchiya and J. Hosoi, Fragrance J., 24, 26 (1996).

2. S. Inoue and S. Kawanishi, FEBS Lett., 371, 86 (1995).

3. V.P. Skulachev, FEBS Lett., 423, 275 (1998).

4. T. Yoshikawa, S. Kokura, K. Tainaka, K. Itani, H. Oyamada, T. Kaneko, Y. Naito and M. Kondo, Cancer Res., 53, 2326 (1993).

5. T. Yoshikawa, S. Kokura, H. Oyamada, S. Iinuma, S. Nishimura, T. Kaneko, Y. Naito and M. Kondo, Cancer Res., 54, 5033 (1994).

6. A. Ohta, Materials for Functional Food, CMC Publishing Co., Ltd., Tokyo, pp. 3-36 (2006).

7. Y. Yamamoto, Chem. Regul. Plants, 35, 169 (2000).

8. Y. Ohmura, K. H. Moon and H. Kashiwadani, Bunrui, 8, 123 (2008).

9. C.H. Kim, J. Iwate Med. Ass., 34, 531 (1982).

10. M. Nakagawa and H. Nagai, Fragrance J., 19, 44 (1991).

11. T. Hashimoto, K. Yoshikawa, N. Kokudo, Y. Asakawa, T. Kimura, T. Inose, A. Hirasawa and G. Tsujimoto, Search for Antidiabetogenic Principles from Edible Mushrooms and Lichen, 3rd Symposium on Pharmaceutical Food Science, Osaka, Japan, pp. 98-100 (2009).

12. T. Hashimoto, N. Kokudo, H. Yano, K. Yoshikawa, A. Umeyama and S. Arihara, Lichenology, 6, 168 (2007).

13. I.B. Repinskaya, Zh. Organicheskoi Khim., 16, 1508 (1980).

14. G. Just, Synth. Commun., 15, 1007 (1985).

15. N. Nakatani, C.H. Kim, H. Kikuzaki, T. Muroi and Y. Matsumura, Chem. Express, 6, 587 (1991).

16. K. Tangdenpaisal, S. Sualek, S. Ruchirawat and P. Ploypradith, Tetrahedron, 65, 4316 (2009).

17. P. Ploypradith, P. Cheryklin, N. Niyomtham, D.R. Bertoni and S. Ruchirawat, Org. Lett., 9, 2637 (2007).
18. M.C. Matos and V.P. Murphy, J. Org. Chem., 72, 1803 (2007).

19. S. Danishefsky, C.-F. Yan, R.K. Singh, R.B. Gammill, P.M. McCurry, N. Fritsch and J. Clardy, J. Am. Chem. Soc., 101, 7001 (1979).

20. T. Abe and M. Nomura, Aroma Res., 7, 56 (2006).

21. S. Ode, Dokkyo J. Med. Sci., 37, 69 (2010).

22. H. Kato and T. Nakatu, Low Temperature and Materials Sciences (Kyoto Univ.), 11, 44 (2007).

23. Z. Woldehiwet and B.K. Horrocks, J. Comp. Pathol., 132, 322 (2005).

24. T. Inoue, Y. Sugimoto, H. Masuda and C. Kamei, Biol. Pharm. Bull., 25, 256 (2002).

25. M.A. Hossen, T. Inoue, Y. Shinmei, K. Minami, Y. Fujii and C. Kamei, Biol. Pharm. Bull., 29, 64 (2006).

26. A.T. Gomes, N.K. Honda, F.M. Roese, R.M. Muzzi and L. Sauer, Z. Naturforsch C, 61, 653 (2006).

27. T.I.B. Lopes, R.G. Coelho, N.C. Yoshida and N.K. Honda, Chem. Pharm. Bull., 56, 1551 (2008).

28. J.F. Sanchez, Y.-M. Chiang, E. Szewczyk, A.D. Davidson, M. Ahuja, C. Elizabeth Oakley, J. Woo Bok, N. Keller, B.R. Oakley and C.C.C. Wang, Mol. Biosyst., 6, 587 (2010).

29. Y. Sawai, Nogyo, Seibutsukei Tokutei Sangyo Gijutsu Kenkyu Kiko, Yasai Chagyo Kenkyusho, 6, 23 (2007).

30. T. Katsu, H. Ono, K. Tasaka and Y. Fujita, Chem. Pharm. Bull., 32, 4185 (1984).

31. A.M. Quílez, M.T. Saenz, M.D. García and R. de la Puerta, J. Pharm. Pharmacol., 56, 1185 (2004).

32. T. Tanaka, T. Hirano, S. Higa, J. Arimitsu, M. Kawai, Jap. Soc. Comple. Alter. Med., 3, 1 (2006).

33. M.E. Marinova, V.N. Yanshlieva and R.I. Totseva, J. Food Sci. Technol., 37, 145 (2008).

34. S.I. Rizvi and K.B. Pandey, Pharmacol. Reports, 62, 726 (2010). 